\title{
Concentrations of Polyamines in Fresh-Water Fishes*1
}

\author{
Hideaki Yamanaka, ${ }^{* 2}$ Kuniyoshi Shimakura, ${ }^{* 2}$ Kazuo Shiomi, *2 \\ Takeaki Kikuchi, ${ }^{* 2}$ Haruka Iida, ${ }^{* 3}$ and Koji Nakamura*3
}

(Accepted March 17, 1987)

\begin{abstract}
The concentrations of polyamines in the tissues of five live fresh-water fishes were determined by gas chromatograph equipped with a flame ionization detector. Spermine (Spn), spermidine (Spd) and putrescine (Put) were distributed in the tissues in general; Spn was largest, followed by Spd, and Put was smallest in quantity. Loach Misgurnus anguillicaudatus was lacking in Spn and Put, and contained cadaverine (Cad) in the muscle and skin. Cad was also detected in the skin of eel Anguilla japonica. A large amount of Spn was determined in the spermary of carp Cyprinus carpio $(103 \mathrm{mg} / 100 \mathrm{~g})$. During the storage at $5^{\circ} \mathrm{C}$, the level of $\mathrm{Spn}$ in the muscle of carp decreased gradually as decomposition progressed and that of Spd was almost constant. The levels of Put, Cad and tyramine increased remarkably after initial decomposition.
\end{abstract}

Polyamines are ubiquitous in biological materials, and are not only produced by the decarboxylation of bacterial enzymes but also biosynthesized in animal and vegetable cells. ${ }^{1)}$ Studies on polyamines in fishes and marine invertebrates have been carried out only by several scientists. Takagi et al. ${ }^{2,3)}$ reported that putrescine (Put), cadaverine (Cad) and tyramine (Tym) were produced during the putrefaction of squid, octopus and shellifishes. Karmas and Miet $z^{4)}$ showed that the formation of Put, Cad and histamine ( $\mathrm{Hm})$, and the loss of spermidine (Spd) and spermine $(\mathrm{Spn})$ were observed as decomposition of albacore progressed, and these polyamines might serve as quality indicators of tuna. Ritchie and Mackie ${ }^{5)}$ indicated that the production of $\mathrm{Hm}, \mathrm{Cad}$ and Put was observed during the storage of mackerel and herring. Yamanaka et al. ${ }^{\text {s) }}$ reported that the levels of Put, Cad, Tym and tryptamine (Tpm) in the meats of sardine and saury pike increased as decomposition progressed regardless of storage temperatures, and of these four polyamines a maximum formation was observed for Cad which seemed to be the most useful index for decomposition of fishes. These polyamines in fishes and marine invertebrates are considered to be produced by the decarboxylation of bacterial enzymes. However, there have been no research works so far that the concentrations of polyamines in live fishes and marine invertebrates were investigated. Polyamines in the muscle and the viscera of live fresh-water species were determined. In addition, changes in polyamine levels were examined in the muscle of carp during the storage at $5^{\circ} \mathrm{C}$.

\section{Materials and Methods}

\section{Fish Samples}

Samples were obtained from freshly sacrificed carp Cyprinus carpio, rainbow trout Salmo gairdnerii, eel Anguilla japonica, loach Misgurnus anguillicaudatus and snake-head Ophicephalus argus.

\section{Determination of Polyamines}

The polyamines (Put, Cad, Tym, Tpm, Spd and Spn) were determined, according to the method of Yamamoto et al. $\left.{ }^{7}, 8\right)$ with some modifications. Five grams of fish sample (muscle, gonad or skin) was homogenized with $20 \mathrm{ml} 2 \% \mathrm{HClO}_{4}$ in a homogenizer and centrifuged at $3,500 \mathrm{rpm}$ for $10 \mathrm{~min}$. This procedure was repeated, and supernatant fluid was removed and combined. The combined supernatants were made up to $50 \mathrm{~m} l$ with $2 \% \mathrm{HClO}_{4}$. This solution was filtered before application to the cation-exchange resin column when it was not clear. A $20 \mathrm{~m} l$ portion of this solution was loaded on a column ( $9 \mathrm{~mm}$ i.d.)

*1 This study was presented at the annual meeting of the Japan. Soc. Sci. Fish., Tokyo, April, 1985.

*2 Department of Food Science and Technology, Tokyo University of Fisheries, Konan 4, Minato, Tokyo 108, Japan (山中英明; 嶋會邦募, 塩見一雄, 菊池武昭：東京水産大学食品生産学科).

*3 Tokai Regional Fisheries Research Laboratory, Kachidoki 5, Chuo, Tokyo 104, Japan (般田 倦, 中村弘 二: 東海区水産研究所) 
containing a $3 \mathrm{~m} /$ bed volume of Amberlite CG-120 $\left(\mathrm{H}^{+}\right.$form) cation-exchange resin. The column was washed with $30 \mathrm{~m} /$ of $0.1 \mathrm{M}$ sodium phosphate buffer ( $\mathrm{pH} 8.0$ ) containing $0.1 \mathrm{M} \mathrm{NaCl}$ and then with $30 \mathrm{ml}$ of $1 \mathrm{~N} \mathrm{HCl}$. Polyamines were eluted with $50 \mathrm{~m} l$ of $6 \mathrm{~N} \mathrm{HCl}$ and $1 \mathrm{~m} l$ of internal standard solution (1,8-diaminooctane) was added to the eluate. The eluate containing the internal standard was evaporated to dryness in a rotary evaporator at $50^{\circ} \mathrm{C}$ in vacuo. The residue was transferred to a $15 \mathrm{~m} l$ test tube with screw cap using $2 \mathrm{~m} l$ distilled water. To the sample solution in a test tube were added $0.5 \mathrm{ml} 10 \% \mathrm{NaOH}$ and 0.2 $\mathrm{m} l$ ethyl chloroformate, and the mixture was shaken for $10 \mathrm{~min}$ at room temperature $\left(20^{\circ} \mathrm{C}\right)$. The resulting ethyloxycarbonyl derivatives of polyamines were extracted three times with $2 \mathrm{~m} l$ of diethyl ether, and the combined ether extracts were evaporated to dryness at $50^{\circ} \mathrm{C}$ with a gentle current of nitrogen. The excess of reagent must be removed at this stage. The residue was dissolved in $0.1 \mathrm{~m} l$ ethyl acetate, and the solution was dried over anhydrous $\mathrm{Na}_{2} \mathrm{SO}_{4}$. A $6 \mu \mathrm{l}$ aliquot of this solution was injected into the gas chromatograph. Analyses were performed on a Hitachi 163 gas chromatograph equipped with a flame ionization detector (FID). A glass column $(1 \mathrm{~m} \times 3 \mathrm{~mm}$ i.d.) was prepared with mixed-phase column packing, $1.5 \%$ OV-17, $0.2 \%$ SP-1000 on $100-200$ mesh Uniport HP (Gasukuro Kogyo, Tokyo). The packed column was preconditioned at $270^{\circ} \mathrm{C}$ for $20 \mathrm{~h}$ with a nitrogen flow rate of $30 \mathrm{ml} / \mathrm{min}$. The operating conditions were as follows: nitrogen flow rate, $60 \mathrm{~m} / / \mathrm{min}$; injection port and detector temperature, $280^{\circ} \mathrm{C}$; oven temperature programmed from $145^{\circ} \mathrm{C}$ to $265^{\circ} \mathrm{C}$ at $5^{\circ} \mathrm{C} / \mathrm{min}$. Peak heights of polyamines and the internal standard were measured and the amounts of each polyamine in samples were determined by comparing the peak height ratios obtained from samples with those from a standard mixture.

\section{Measurement of $\mathrm{pH}$}

$\mathrm{pH}$ of the muscle was measured with the homogenate of sample in five volumes of distilled water.

\section{Determination of Volatile Basic Nitrogen (VBN)}

VBN of the muscle was determined by the micro-diffusion method of Conway. ${ }^{0)}$

\section{Measurement of Viable Counts of Total Bacteria}

Ten grams of the muscle was homogenized with $90 \mathrm{ml}$ of sterile $0.9 \%$ saline water in a sterile blender for $2 \mathrm{~min}$. Serial 10 -fold dilutions of the homogenate were made with sterile $0.9 \%$ saline water and each $0.1 \mathrm{~m} l$ of the dilutions was spread over an agar plate $(\mathrm{pH} 7.0)$ with the following composition: peptone (Daigo), $5 \mathrm{~g}$; beef extract (Kyokuto), $2.5 \mathrm{~g}$; yeast extract (Difco), $2.5 \mathrm{~g}$; glucose, $1 \mathrm{~g}$; agar, $20 \mathrm{~g}$; and distilled water, $1,000 \mathrm{ml}$. Colonies on the plate were counted after the incubation for 10 days at $20^{\circ} \mathrm{C}$. Triplicate experiments were made for each dilution.

\section{Results and Discussion}

Fig. 1 depicts the chromatogram of ethyloxycarbonyl derivatives of polyamines (Put, Cad, Tym, Tpm, Spd and Spn). These polyamines could be separated clearly from each other. The chromatogram of polyamines in the spermary of carp is shown in Fig. 2. Put, Spd and Spn were detected in the spermary. In Fig. 3 are illustrated the contents of polyamines in the muscle and gonad of carp. Spn, Spd and Put were detected

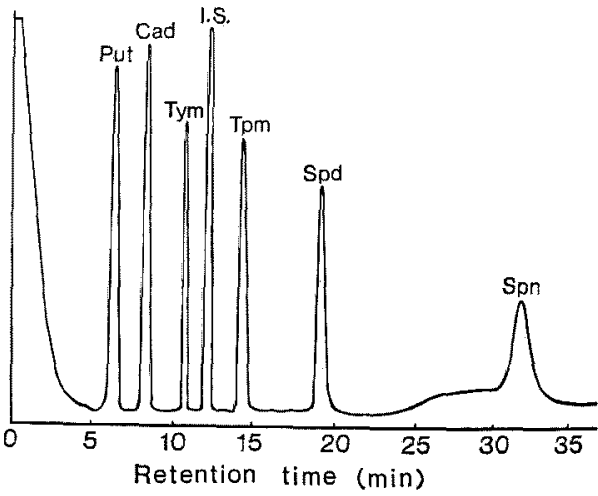

Fig. 1. Gas chromatogram of standards of polyamines.

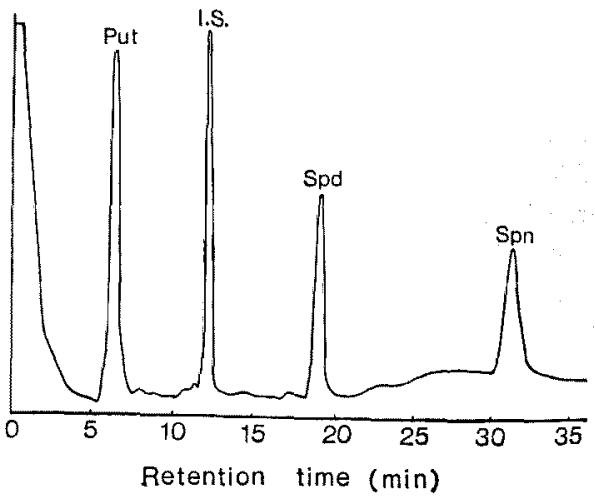

Fig. 2. Gas chromatogram of polyamines in the spermary of carp. 


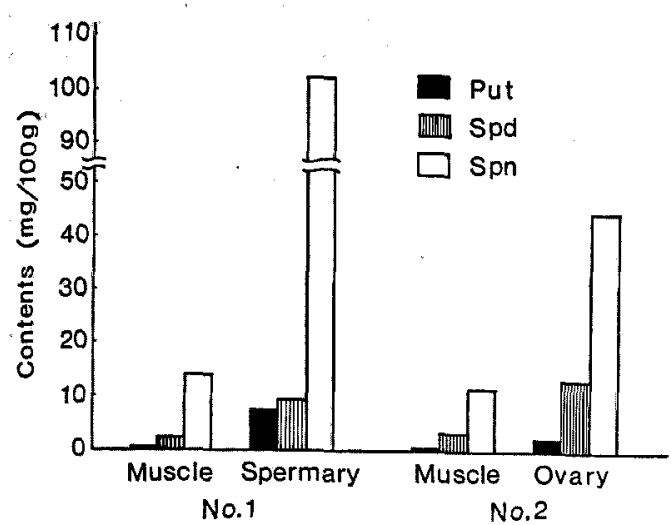

Fig. 3. Contents of polyamines in the muscle and gonad of carp.

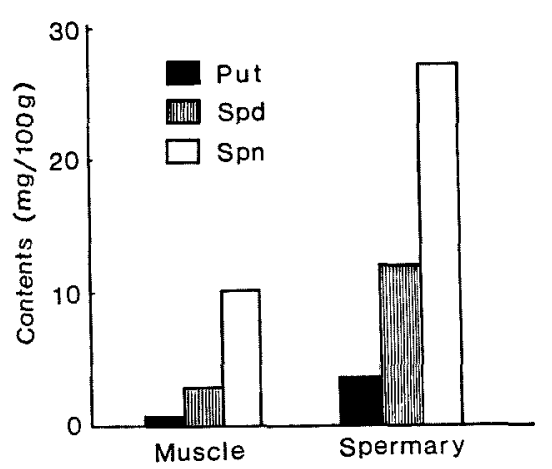

Fig. 4. Contents of polyamines in the muscle and spermary of rainbow trout.

in the muscle, spermary and ovary. A large amount of Spn was detected in the spermary (103 $\mathrm{mg} / 100 \mathrm{~g}$ ) and the ovary $(46 \mathrm{mg} / 100 \mathrm{~g})$, and a fairly large large amount of Spn was present in the muscle $(12$ to $14 \mathrm{mg} / 100 \mathrm{~g})$. Spd was observed at the considerably high concentrations in the ovary $(14 \mathrm{mg} / 100 \mathrm{~g})$ and the spermary $(10 \mathrm{mg}$ ) $100 \mathrm{~g}$ ) and at the low concentrations in the muscle ( 2 to $3 \mathrm{mg} / 100 \mathrm{~g}$ ). A fairly large amount of Put was determined in the spermary $(8 \mathrm{mg} / 100 \mathrm{~g})$. The muscle of carp had a smell of semen and its smell was none other than that of Spn. The contents of polyamines in rainbow trout are shown in Fig. 4. Spn, Spd and Put were detected in the same manner as carp. Spn was observed at the concentrations of $28 \mathrm{mg} / 100 \mathrm{~g}$ in the spermary and $10 \mathrm{mg} / 100 \mathrm{~g}$ in the muscle of rainbow trout. In Fig. 5 are illustrated the contents of polyamines in eel. In the muscle Spd and Spn were detected at the concentrations of 2 to $3 \mathrm{mg} / 100 \mathrm{~g}$, but Put did not exist. On the other hand, Spn, Spd, Put and Cad were detected in the skin, and the con-

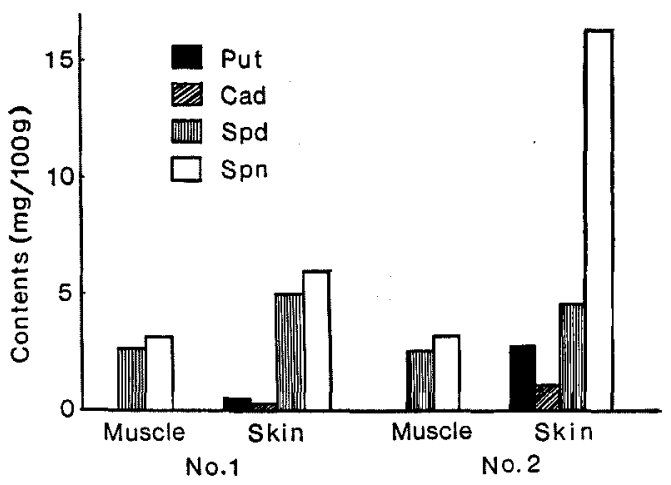

Fig. 5. Contents of polyamines in the muscle and skin of eel.

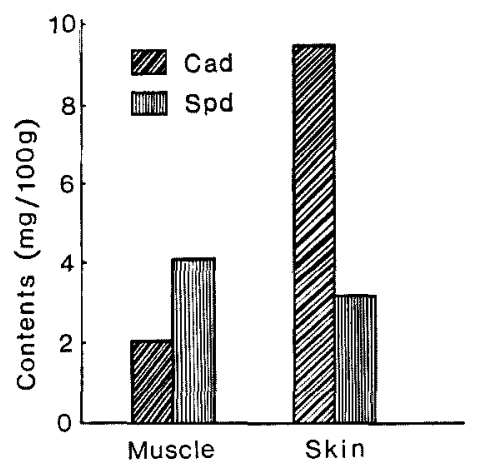

Fig. 6. Contents of polyamines in the muscle and skin of loach.

centractions of Spn were 6 to $16 \mathrm{mg} / 100 \mathrm{~g}$ and those of Spd were about $5 \mathrm{mg} / 100 \mathrm{~g}$. It is characteristic that a small amount of Cad was observed in the skin of eel. The results in the muscle and skin of loach are shown in Fig. 6. It is very interesting that Cad and Spd were detected, but Spn and Put were not present in loach. Particularly, a fairly large amount of Cad was determined in the skin $(9.5 \mathrm{mg} / 100 \mathrm{~g})$. In Fig. 7 are illustrated the contents of polyamines in snake-head. Spn, Spd and Put were detected. The contents of Spn were high in the muscle and skin, and fairly large amounts of Spd $(9 \mathrm{mg} / 100 \mathrm{~g})$ and Put $(5 \mathrm{mg} / 100 \mathrm{~g})$ were detected in the skin.

From these results, it is obvious that Spn, Spd and Put are distributed in the tissues of the live fresh-water fishes in general; Spn is largest, followed by Spd and Put is smallest in quantity. This conclusion is consistent with the data in Mammalia by Tabor and Tabor. ${ }^{1)}$ It is interesting that loach is lacking in Spn and Put, but contained Cad specifically in the muscle and skin, and that Cad is also detected in the skin of eel. In this 


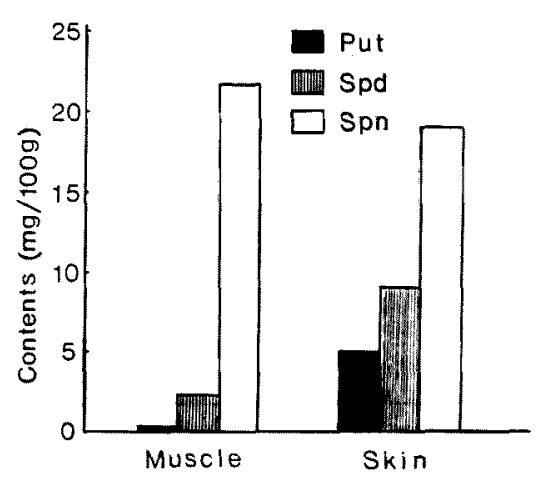

Fig. 7. Contents of polyamines in the muscle and skin of snake-head.
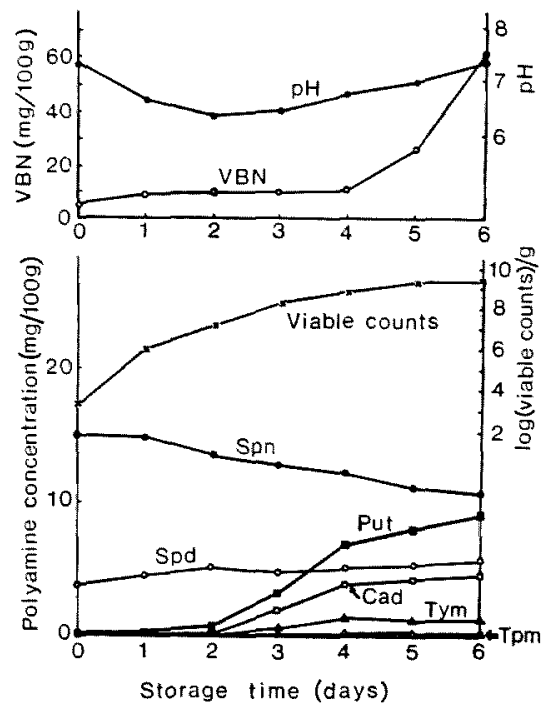

Fig. 8. Changes in contents of polyamines, VBN, $\mathrm{pH}$ and viable counts of total bacteria in the muscle of carp during the storage at $5^{\circ} \mathrm{C}$.

experiment a large amount of $\mathrm{Spn}$ was determined in the spermary of carp $(103 \mathrm{mg} / 100 \mathrm{~g})$ and rainbow trout $(28 \mathrm{mg} / 100 \mathrm{~g})$, while Tabor and Tabor. ${ }^{1)}$ reported that the contents of Spn were $62 \mathrm{mg} / 100 \mathrm{~g}$ in the seminal plasma of human and $96 \mathrm{mg} / 100 \mathrm{~g}$ in the prostate of rat.

As mentioned above it was ascertained that polyamines are biosynthesized in the tissues of fresh-water fishes. It was examined next what kinds of polyamines were newly produced by bacterial enzymes and in what manner the poly- amines occurring originally in the live fresh-water fishes changed during storage. So, using the muscle of carp, the changes in contents of polyamines were investigated during the storage at $5^{\circ} \mathrm{C}$. VBN, $\mathrm{pH}$ and viable counts of total bacteria were also measured. The results are shown in Fig. 8 collectively. The muscle gave off a faintly putrid smell on the 2 nd day from the starting point and this stage was that of initial decomposition. The $\mathrm{pH}$ of the muscle started at 7.3 , gradually decreased for 2 days and thereafter increased again; the lowest value (6.4) was obtained at the stage of intial decomposition. VBN increased rapidly after 5 days. The viable counts of total bacteria increased with storage time and reached the level of $10^{7} / \mathrm{g}$ at the stage of initial decomposition. The level of Spn decreased gradually as decomposition progressed and that of Spd was almost constant during storage. In contrast, the levels of Put, Cad and Tym increased as decomposition progressed and the increase after initial decomposition was remarkable. Tpm was not detected throughout the experiments.

\section{References}

1) C. W. Tabor and H. Tabor: Ann. Rev. Biochem., 45, 285-306 (1976).

2) M. Takagi, A. Iida, H. Murayama, and S. Soma: Bull. Fac. Fish. Hokkaido Univ., 21, 133-143 (1970).

3) M. Takagi, A. Iida, and S. Oka: Nippon Suisan Gakkaishi, 37, 1079-1083 (1971).

4) E. Karmas and J. L. Mietz: Lebensm. Wiss. Technol., 11, 333-337 (1978).

5) A. H. Ritchie and I. M. Mackie: In "Advances in Fish Science and Technology" (ed. by J.J. Connell), Fishing News Books Ltd., Farnham (England), 1980, pp. 489-494.

6) H. Yamanaka, K. Shimakura, K. Shiomi, and T. Kikuchi: Nippon Suisan Gakkaishi, 52, 127-130 (1986).

7) S. Yamamoto, S. Wakabayashi, and M. Makita: J. Agric. Food Chem., 28, 790-793 (1980).

8) S. Yamamoto, H. Itano, H. Kataoka, and M. Makita: J. Agric. Food Chem., 30, 435-439 (1982).

9) E. J. Conway: Microdiffusion Analysis and Volumetric Error, 3rd ed., Crosby Lockwood and Son Ltd., London, 1950, pp. 87-107. 